\title{
USING OF OPTIMIZING METHODS IN INVENTORY MANAGEMENT OF THE COMPANY
}

\author{
Katarína Teplická \\ Technical University of Košice, FBERG, Letná 9, 04201 Košice, Slovak Republic, EU, \\ katarina.teplicka@tuke.sk (corresponding author) \\ Katarína Čulková \\ Technical University of Košice, FBERG, Letná 9, 04201 Košice, Slovak Republic, EU,
} katarina.culkova@tuke.sk

Keywords: deficit, inventory, model, optimization

Abstract: Management of inventory presents an integral part of logistics and effective inventory management demands inventory optimizing since the stocks of the company bind financial resources and present high costs on stocking and maintenance of inventory. The aim of this contribution is to point out the possibilities of optimization the stocks of the mining company in the process of extracting granodiorite. For optimization of stocks - granodiorite we can use EOQ inventory optimization model is used, which sets the optimal amount of raw material extracted in relation to economic indicators such as storage costs, the cost of securing the extracted material in the quarry, insurance costs and other types of costs. By EOQ optimization model, we found that optimum granodiorite extraction should be 38 tons per hour of granodiorite, which would mean low costs for the company in relation to securing the raw material. This model allows planning interventions in the mining process in terms of cost optimization, which is an important economic indicator for the company. The advantage of this EOQ model is the obtaining of important information about the state of the extracted raw material in the quarry Hradbová as well as on the volume of storage costs of the extracted raw material. Management of stocks raw material and minimization of costs represent economic benefits for the mining company.

\section{Introduction}

Effective management of inventory in the company must be planned from the first activity that relates to stocks purchase. It is necessary to understand what stocks the company needs, in what volume, when to order stocks, how to transport stocks to the company, etc. All mentioned information must be followed up through planned information systems for the area of inventory management in the companies, which are presently very different, based on the principle of simulation, operation research, statistical methods, etc. [1]. During management of stocks level, we can use also quantitative methods of operation analysis that can have stochastic and deterministic character [2]. In the practice the most often used is the deterministic model of stock management without deficit, known as EOQ model - economic order quantity, introduced by Ford W. Harris in 1913 and lately R.H. Wilson develop the model [3].

Effective inventory management is necessary assumption the company could provide fluent production process or continual business supply. Stocks in the practice present many times property that binds financial means of the company and there is no possibility to transform stocks to the financial means rapidly. Modern inventory management should be based on three basic pillars, mainly value creation, shortening of the ongoing period and capacity using, as well as monitoring of stocks volume in relation to the economic indexes, as for example productivity and liquidity [1].
Inventory of the company must be planned, organized in the process of holding and stocking, controlled during expenditure to the consumption. The optimal volume of inventory at the stocks is the assumption of effective inventory management, decreasing of costs on stocking and holding, as well as using all supply capacities. Not necessary stocks bring the loss for the company and their ineffective using in further production process. Presently there is a trend of inventory management, orientated to the Japan approach JIT (Just in Time), which means maintaining stocks only in a volume that is demanded for the given production process. State of inventory at the stocks is decreasing and stocks are ordered by the operative way according to the need of the production process. But not all companies can use such approach and in case of necessity to stock inventory also a quantitative determination of optimal stocks volume presents a contribution [4].

\section{Literature review}

The topic of sustainable supply chains has evoked considerable interest from academics and practitioners. Ghadimi et al. (2019) revealed that the call for incorporating sustainability (i. e., economic, social, and environmental pillars) into supply chain operations has increased in recent years, mainly in connection with supply chain management [5]. Cost-effective supply chain management under various market, logistics and production uncertainties is a critical issue for companies in the industry. Uncertainties in the supply chain usually 
increase the variance of profits (or costs) to the company, increasing the likelihood of decreased profit. New innovative technologies are required, improving the efficiency of the processes and the optimization of global supply chains (GSC) in order to establish sustainability in environmental, social, and economic aspects. Kovács and Illés (2019) formed the optimal combination of the suppliers, final assemblers, and service providers to achieve cost-effective, time-effective, and sustainable operation [6].

According to Kovács and Kot (2016) fast-changing market environment and fluctuating customer demands, as well as inventory management, require efficient operation of logistical processes [7]. Therefore, in connection with SCM inventory management is presently considered as a global operations strategy for achieving competitiveness of the company through finding flexibility and responsiveness. Inventory management is a basic element of production and financial management. It was proved that inventory in the current volatile environment are an important determinant of an organization's effectiveness and sustainability, on the one hand, and a guarantee of liquidity, on the other hand [8].

In many production environments where demand and lead times are variable, significant levels of safety stock inventory are required to assure timely production and delivery of the final product [9]. Safety stock levels are commonly introduced in the supply chain. In this connection Jung et al. (2004) used deterministic planning and scheduling models, which incorporate safety stock levels [10].

Inventory optimization is the process of ensuring the right product at the right place, right time, right quantity and right quality to meet the demand and supply of goods and or services. To optimize inventory management can be by classifying inventory and demand forecasting model for better prediction of demand to manage inventory [11]. Armenzoni et al. (2015) suggested the model, providing estimation of the optimal level of inventory the company should keep available, using 'traditional' and an 'advanced' approach for demand forecasting, which underline the efficiency of inventory management [12].

Also, the application of operations research methods and related models, for inventory management has been effectively searched by various authors [13]. For example, Bertrand and Fransoo (2002) give an overview of quantitative model-based research in inventory management, concluding that methodology of quantitative research offers a great opportunity for operations in inventory management [14]. But according Gunasekaran and Ngai (2004) there is gap in implementation of IT to inventory management [15].

Berling and Marklund (2013) presented an approximation model for optimizing inventory, motivated by close cooperation with a supply chain management of the company, using costs optimizing [16], when Andersson and Marklund (2000) used an approach, based on an approximate cost evaluation technique during inventory control [17]. The research is necessary to be done by exact cost evaluation. Moreover, inventory costs are strongly affected by the shape of the assumed LTD distribution, but it can be difficult to set the reorder point in an inventory system because often one does not have much knowledge of the lead-time demand (LTD) distribution [18].

Ogbo et al. (2014) took into consideration the relationship between effective system of inventory management and organization performance, showing that flexibility in inventory control management is an important approach to achieving organizational performance [19]. There is a relationship between operational feasibility, utility of inventory control management in the customer related issues of the organization and cost effectiveness technique are implemented to enhance the return on investment in the organization. Effective inventory control management is recognized as one of the areas, management of any organization should acquire capability.

Luo et al. (2015) investigated a purchase-inventory optimization problem arising from the operation management practice [20], suggested the model for the iron and steel industry. In the cost-oriented purchase problem, the demands during future planning periods are unknown, therefore new models are necessary. But there is still a gap in using of inventory optimization in the mining industry and extraction companies. Siponen et al. (2019) indicated that in inventory management there are shortages due to inadequate control and management policies and procedures [21]. There is necessary to develop inventory operations, including material management, supplier management and IS management [22]. This can lead to improvements in inventory control and productivity while reducing operational costs. The goal of the contribution is therefore to bring new important information about optimizing in inventory management in mining organizations.

\section{Methodology}

The goal of the deterministic model of inventory management in the company is the optimization of a basic parameter of the model, which means ordered volume of stocks - known as supply (Q) and level of stocks order (r), regarding economic criteria of all annual costs from supply process that must be minimized. The model solves two basic questions:

1. What volume of stocks to order? - the optimal volume of stocks (Q).

2. When to order the stocks? - determination of order level (r). 


\section{USING OF OPTIMIZING METHODS IN INVENTORY MANAGEMENT OF THE COMPANY}

Katarína Teplická; Katarína Čulková

Basic starting points for EOQ (economic order quantity) model using are as follows:

1. Consumption is known, expressed per year - year presents a basic planed period.

2. Consumption during the year presents a continuous function in time, having uniform flow.

3. Delivery time is exactly known, always the same.

4. Volume of supply is not limited, taking place at the same time.

5. Stocking is not limited and there is no influence of aging.

6. Model is stationary; therefore, the volume of supply and delivery time are always the same.

Input parameters of the model present:

$\lambda$ - intensity of stocks consumption - consumption of stocks for certain time interval, expressed in units of volume per time period of the year - as basic planed period. Consumption of stocks can have character of season consumption, which has non-stationary character, changing in time or not season consumption that has stationary character, not changing in time.

$\tau$ - delivery time - characterizing time delay - time between moment of stocks ordering and moment of supply to inventory.

Resulting parameters of the model present:

Q - optimal volume of order - ordered volume of stocks that must be equal supplied volume of stocks to the inventory. Value (Q) characterizes volume of stocks that are once supplied to the stock, while this volume is gradually consumed according to intensity of production process or demand claims.

r- level of stocks ordering - level of stocks, to which stocks would decrease, there is necessary to order supply of new stocks during in ahead agreed ordering and supplying conditions, with aim the ordered supply could come in time to the stock or in time, when real stock achieves level of insurance stocks.

$\mathbf{r}_{\mathbf{t}}$ - time of ordering - determined according level of ordering, presenting time of stocks decrease under level of ordering.

Through mentioned model parameters there is possible to solve target question of the model for inventory management without deficit.

$\mathbf{t}_{\text {d }}$ - supply cycle - characterizing time between order arriving to the stock and moment of all stock's consumption. This index depends on intensity of stock consumption and volume of order.

$\mathbf{v}$ - turnover of stocks - inverse value of supply cycle, expressing number of cycles of stocks supply during the analysed period.

The purpose function of the deterministic model has cost character. The purpose function presents the function of total annual costs for management of inventory process, known as: Nc (Q). The goal of the function optimizing is finding of minimal value of annual costs on stocking, from a mathematical point of view it means searching for free extreme genuinely convex function (Figure 1).

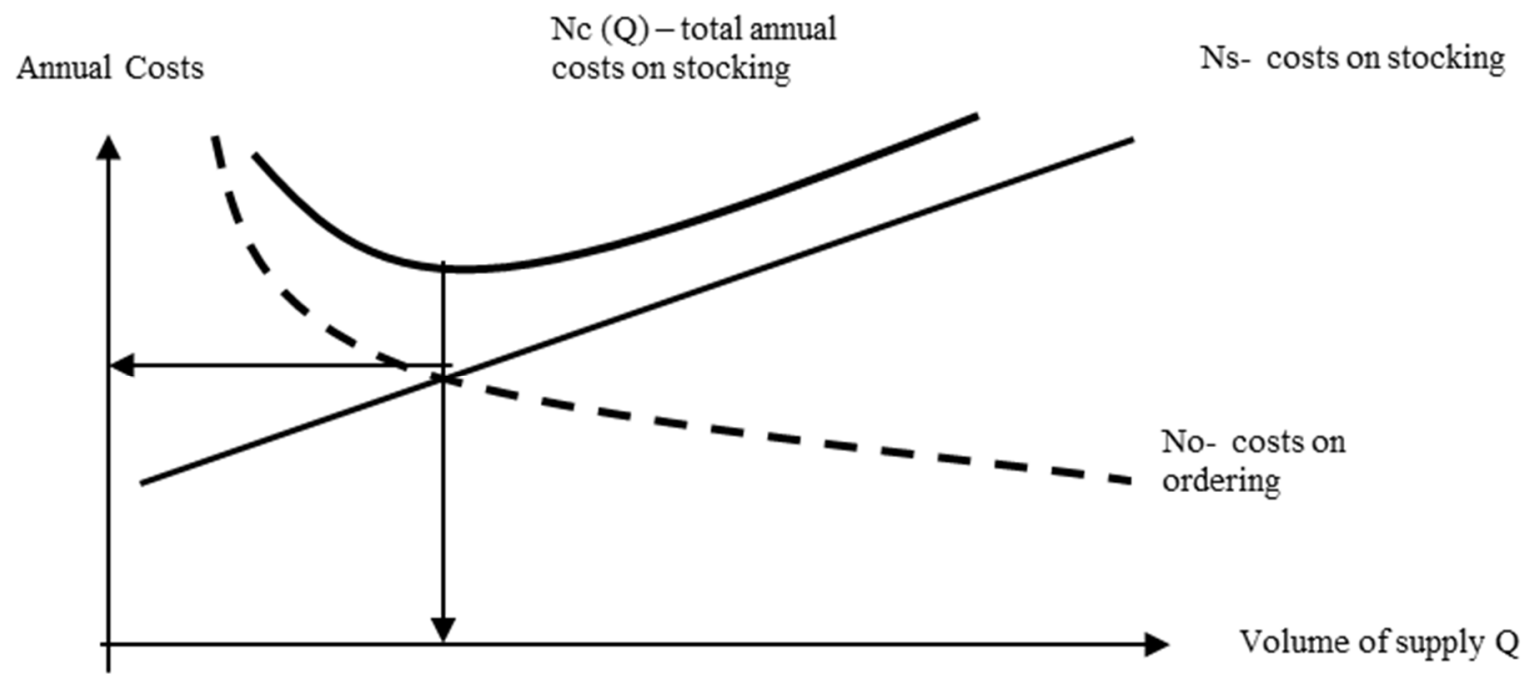

Q optimal volume of supply

Figure 1 Expression of purpose function for deterministic model Source: Ivaničová, Brezina, 1997 [23] 
Purpose function of the deterministic model consists of the following parameters:

Costs of ordering (supply) (No) - costs, connected with one stock supply, for example, costs on ordering, telephone fees, fax, mailing, part of transport costs, consumption of office supplies, consumption of administrative supplies, costs on invoices liquidation, costs, connected with orders following, reclamation, exceptional costs, connected with damages, special interventions, organizational shortages during stocking, wages of employees that follow up income of supply, stocking, financing with suppliers, etc. Such costs for one supplied unit during a bigger volume of supplied stocks are decreasing. To this group of costs, there is not included ordering price of stocks. The level of the stocks must depend on a few supplies. Such costs are determined by the normative or statistical way [24].

Costs on stocking (Ns) - connected with stocking and maintenance of inventory, expressed in values per unit of stocks and time interval (day), dependent on stocking volume, which means they grow proportionally with volume of supply. Such costs are considerable, while free stocking spaces are further rent to someone, or when with higher stocks volume the company must pay for other rented spaces, electricity, heating, etc. Part of such costs are also interesting from credits for stocks payment, costs for losses, connected with inventory depreciation, damaging and destruction of costs, costs, connected with covering of other damages, insurance of stocks, costs for proper physical and chemical maintenance of stocks, costs on stocking spaces, maintenance of spaces, depreciation and repairs, manipulation stocks, connected with stocks transitions, etc.

Optimization of purpose function has a character of minimizing. Mathematically it means searching of a free extreme of a genuinely convex function. The minimum is found by derivation of purpose function (1), equal zero.

$$
\begin{gathered}
N c(Q)=N o+N s \\
\frac{d N c(Q)}{d Q}=-\frac{\lambda}{Q^{2}} \times N o+\frac{N s}{2}=\mathbf{0}
\end{gathered}
$$

By the mathematical expression of the purpose function we can determine the equation for the calculation of total costs on supply and stocking during optimal supplies followed (2):

$$
\left.N_{C}=\frac{\lambda}{Q_{o p t}} \times N o+\frac{Q_{o p t}}{2} \times N_{S} \quad \text { (value units }-€\right)
$$

The purpose function expressed as the sum of the cost of ordering and of the cost of stocking creates the total cost. Total costs use the optimal parameter - optimal volume of stock based on the Wilson-Adler formula by equation 3 .

\subsection{Model EOQ (Economic order quantity)}

Model EOQ means a solution of purpose function. We look for a minimum of total cost. We obtain information of total cost minimum and also about the optimal volume of stock. The calculation of the optimal volume of stock is known as Wilson-Andler equation (3). For this formula we need to know the intensity of stock consumption, ordering cost, stocking cost. That information is pointed out in financial accounting. The information is a very important source for the process of optimization of costs and volume of stocks.

$$
Q_{\mathrm{opt}}=\sqrt{\frac{2 \times \lambda \times N o}{N_{S}}}(\text { quantity units }- \text { pieces, } \mathrm{kg} \ldots)
$$

In assumption that supplies are determined in optimal level, we can derive following relations - optimizing indexes:

\section{Average state of stocks during optimal supplies}

The average state of stocks is determined according to formula 4 as the classical arithmetic mean. This indicator informs us of the average stock level in stock and provides us with information for securing insurance stocks and placing new orders. It is a basic indicator for planning the volume of insurance stocks.

$$
\left.\bar{Q}=\frac{Q}{2} \text { (quantity units }- \text { pieces, } \mathbf{k g} \text {, tones... }\right)
$$

\section{Length of supply cycle during optimal supplies}

The supply cycle is the time interval from the arrival of the stocks in the warehouse to the complete exhaustion of the stocks. It is expressed in time units. This indicator depends on the intensity of stock consumption (5).

$$
\left.t d_{\text {opt }}=\frac{Q}{\lambda} \quad \text { (time units }- \text { day, month }\right)
$$

\section{Turnover - optimal number of realized supply cycles during analysed period}

Turnover of stock is the indicator that it identifies an optimal number of realized supply cycles during the analysed period. This indicator must be minimalized because a few turnovers of stock influences financial indicators and it increases costs.

Number of cycles in analysed period per year (6):

$$
v=\frac{1}{t d_{o p t}}
$$

Question When to order the stocks? we can answer by calculation of the level of ordering (r) and determination of moment for supply ordering to the stock. Total costs are expressed as costs on supply and costs on stocking without acceptance of the purchase price and intensity of stock consumption. Total costs can be 
calculated as a summary function of costs on supply and costs on stocking from the deterministic model of stocks management without a deficit. Total costs are determined for values of optimal supply, decreased by certain percentage and increased by a certain percentage. After the determination of ordering level, we can achieve the second goal of modelling stocks movement without deficit, mainly by answering the question: When to order stocks? Stocks must be ordered in a moment when decreasing under ordering level.

\section{Level of stocks ordering (r)}

The level of stock ordering (7) is a very important indicator because it shows deficit of stocks. This indicator expresses what time is needed for their ordering. At this moment company must order the stocks.

$$
r=\left(\mu-m \times Q^{*}\right)
$$

\section{Coefficient $(m)$}

Consumption during delivery time (8), which is presently an equal volume of supplies on the way (quantitative units).

Coefficient $(m)$ is a number of supplies on the way before the moment of ordering.

$$
m=\frac{\tau}{t_{d}}
$$

Determination of value $(m)$, when comparing delivery time and supply cycle, while the dividing is calculated to the biggest whole number integral factor, for example when $m=2.5$, then $m=2, \mathrm{~m}$ is a dimensionless number.

\section{Results \\ Optimizing the model for raw material in a mining} company

In this contribution, we solved a problem with inventory in the quarry Hradová. By the EOQ model (equation 6) - Wilson Adler equation we looked for optimizing state of inventory raw material granodiorite in a mining company, which extract granodiorite by surface mining for the purpose of adjustment, used as an aggregate in construction. The extracted raw material is stored in the quarry and the mining company solves a place for the storage of raw material - granodiorite (figure 2). Place for store raw material - granodiorite is big problem for mining company, that must be solved. By the optimizing model, we can decrease volume of raw material for a store in the quarry Hradová.

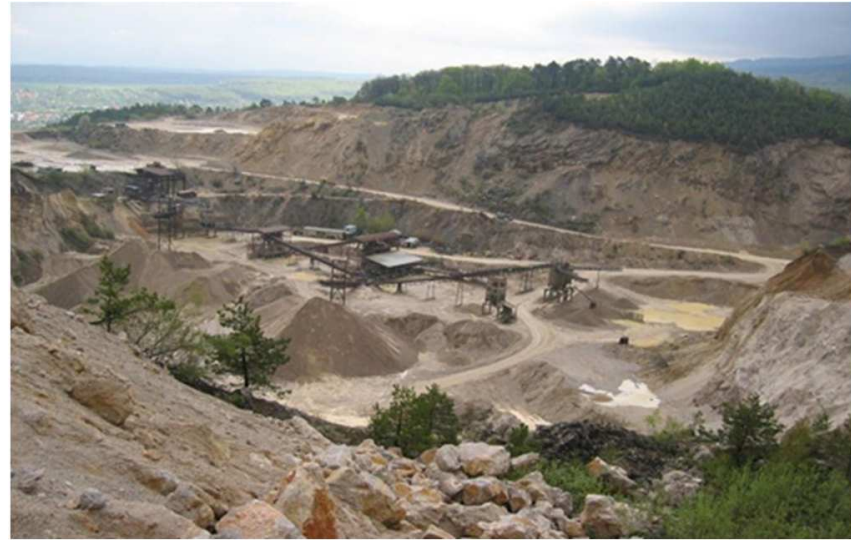

Figure 2 Mining of granodiorite in Hradová quarry

The total process of mining is going from the dump of raw material that is transited by tunnel way to further processing to the material shredder with intensity 140 tons per hour. Average costs connected with a stocking of the aggregate fraction at the dump presents $5 €$ per ton and hour. Costs, connected with the material transition from the dump to tunnel flow of one aggregate supply, present $25 €$. The delivery time of aggregate is approximately 3 days. The goal of this contribution is to determine basic optimizing parameters of the process for stocking of adjusted aggregate (fraction) in the mining company.

Basic information for modelling was obtained from documents from financial accounting. Storage costs were determined by statistical methods from the previous reference period of the raw material storage. Demanded parameters for calculations are given in Table 1.

Table 1 Input parameters for EOQ model

\begin{tabular}{|l|c|}
\hline Costs on ordering $-(\mathrm{No})$ & $\mathbf{2 5} €$ \\
\hline Costs on stocking $-(\mathrm{Ns})$ & $\mathbf{5} € /$ ton $/$ hour \\
\hline Intensity of stocks consumption $-(\lambda)$ & $\mathbf{1 4 0}$ ton/hour \\
\hline Delivery time $-(\tau)$ & $\mathbf{3 ~ d a y s ~}=\mathbf{7 2}$ hours \\
\hline
\end{tabular}

The solution of the problem in the mining company problem will be realized through the mathematical model EOQ on the basis of which we will find out the optimal volume of stocks of raw material - granodiorite and the costs related to securing these stocks in the quarry Hradová. Calculation had been made according to algorithm of the model EOQ without stock deficit by the formula (3). The optimal volume of a fraction that enters the shredder is 38 tons.

$$
Q_{\mathrm{opt}}=\sqrt{\frac{2 \times \lambda \times N o}{N_{S}}}=37.417 \text { tons }
$$

We calculated the average volume of stocks during optimal supply by the formula (4). The volume of average stock represents the amount of the insurance stock in the warehouse, which will not represent a material deficit in the handling process of raw material. 
$\bar{Q}=\frac{Q}{2}=\frac{37.417}{2}=18.7$ tons

We calculated length of supply cycle during optimal supplies by the formula (5).

$t d_{o p t}=\frac{Q}{\lambda}=\frac{37.417}{140}=0.267$ hours

We calculated turnover - optimal number of realized supply cycles during analysed period by the formula (6).

$v=\frac{1}{t d_{o p t}}=\frac{1}{0.267}=3.74$ cycles per hour

We calculated total costs of supply and stocking during optimal supplies by the formula (2).

The cost is related to the optimum stock of material that must be in the quarry for the further process of processing the material into fractions.

$N_{C}=\frac{\lambda}{Q_{o p t}} \times N o+\frac{Q_{o p t}}{2} \times N_{S}=187.0829$ Eur

We calculated level of stocks ordering (r) by the formula $(7,8)$.

To answer the question When to order the stock? we can answer by the way of calculations of ordering level (r) and by determination of moment for supply order to the inventory. After the determination of ordering level, we can meet the second goal of the modelling of stocks transition without the deficit and to answer the question: When to order the stocks? Stocks are ordered in time when they decrease under ordering level, which means in the case 15 tons.

We used calculation:

$$
r=\left(\mu-m \times Q^{*}\right)=140 \times 72-269 \times 37.417=15 \text { tons }
$$

According to the calculations of optimizing parameters, we can state that the optimal volume of granodiorite is 38 tons, which should enter the shredder from the dump. If the level of material decreases to level 15 tons, there is necessary to provide material inflow from the dump by tunnel flow to shredder. The length of the supply cycle of the material, which means granodiorite to shredder presents 0.267 hour, which means material supply through the tunnel to the shredder from the dump is made averagely three times per hour. Total costs that could be achieved during optimal supplies of granodiorite in the shredder present 187 Eur per one supply of material from the dump to the shredder.

\section{Discussion}

Using quantitative models in the practice is necessary from the view of managerial decision and management of stocking processes. The companies are presently trying to minimize the level of their stocks, using operative inventory management with an aim to minimize stocks on stocking and inventory. Also, according to the model, there is possible to influence and manage stocks supply to the inventory and by this way to optimize costs on purchase and stocking. Decreasing of stock level presents for some companies' big problems since they have stocks, which are not saleable, useless. And the EOQ model is therefore the tool how the company could manage their stock situation and to order optimal volume of stock that are able to be consumed in the frame of the production process or to be sold in the frame of distribution or sale. The period of logistic management presently prioritizes the stocking, leading to decreasing of stocks situation, decreasing costs on stock maintenance, decreasing costs on stocking and principle of purchase marketing.

Systematic improvement of the stocking process brings improvement for the companies that lead to the permanent improvement of business outputs. The goal of improvement for stocking and supply processes is their optimizing and removing of wasting in processes, which is influenced by the quality and productivity of the company. Companies are presently trying to adapt to the rapidly changing conditions at the market and to react to the changes flexibly and effectively, and they must increase their performance. This is reflected mainly through main processes, such as a process of stocking and supplying.

This optimizing model is using in various areas of industry, in the area of agriculture, its use is important in business processes and services. We can use optimizing models also in nonmanufacturing sphere for example in health, education service, science, public management and we presented this optimizing model in article Energy solutions based on biomass and using of a quantitative optimization model for a biomass boiler in 2017 in Research Journal of Mining.

\section{Conclusion}

The aim of the paper was to point out the possibilities of optimizing the extracted raw material in the mining company for granodiorite mineral. By using the EOQ optimization model, we found that the optimum extraction of granodiorite should be 38 tons per hour of mineral extraction, which would mean low costs for the company in relation to securing the extracted raw material. At the same time, we found that if a company has less than 15 tonnes of mined granodiorite in the quarry, it must begin another cycle of granodiorite mining and management to meet sales needs and customer requirements.

We have optimized cost items because this way of extraction will extract granodiorite only by a plan, while the costs are optimized. The costs for the company represent the financial resources that the company must create in order to ensure the smooth operation of the extraction of granodiorite and its processing and securing in the stock of the extracted raw material. This model makes it possible to plan interventions in the mining process in terms of cost optimization, which is an important 
economic indicator for the company. The main benefit of operational research models - EOQ that can be used in practice in decision making and management of the mining process are meeting customer expectations and requirements.

Inventory management creates an area for improvements in inventory control and productivity while reducing operational costs for storage, which presents a financial situation of the company. The main task in the area of stocks is minimalizing costs and reducing the volume of stocks at storage. The goal of the contribution was to bring new important information about optimizing inventory management in various companies and as an example we showed an optimizing model of stocks volume in the mining organization. The results of the contribution remove a gap in optimizing stock in the mining organization, remaining space for similar research of stock optimizing in special conditions of surface and underground mining.

\section{Acknowledgement}

This article was supported by the state grant agency KEGA 006TUKE-4/2019 "Transfer of knowledge from the field of logistics into the preparation of innovative teaching materials for selected study units of the newly accredited study program 'Commercial logistics'" and KEGA 049TUKE-4/2019 "Foreign Students' Education with an Emphasis on Creating Key Competences in the Context of Building a Working Career and the Inclusion into the Labor Market in Slovakia".

\section{References}

[1] DUPAL, A, BREZINA, I.: Logistika v manažmente podniku. SPRINT, Bratislava, 2006. (Original in Slovak)

[2] IVANIČOVÁ, Z, BREZINA, I, PEKÁR, J.: Operačný výskum, Edícia Ekonómia, IURA Edition, Bratislava, 2002. (Original in Slovak)

[3] ERLENKOTTER, D.: Ford Whitman Harris and the economic order quantity model, Operations Research, Vol. 38, No. 6, pp. 937-946, 1990. doi:10.1287/opre.38.6.937

[4] TEPLICKÁ, K.: Uplatnenie nástrojov operačnej analýzy $v$ banskom podniku, AMS, TU F BERG, Košice, 2012. (Original in Slovak)

[5] GHADIMI, P., WANG, C., LIM, M.K.: Sustainable supply chain modeling and analysis: Past debate, present problems and future challenges, Resources, Conservation and Recycling, Vol. 140, No. January, pp. 72-84, 2019. doi:10.1016/j.resconrec.2018.09.005

[6] KOVÁCS, G., ILLÉS, B.: Development of an optimization method and software for optimizing global supply chains for increased efficiency, competitiveness, and sustainability, Sustainability, Vol. 11, No. 6, pp. 1-28, 2019. doi: $10.3390 /$ su 11061610
[7] KOVÁCS, G., KOT, S.: New logistics and production trends as the effect of global economy changes, Polish Journal of Management Studies, Vol. 14, No. 2, pp. 115-126, 2016.

[8] CHIBISOV, O.V., CHIBISOVA, E.I., KAZANTSEVA, S.Y.: Improvement of corporate operations in inventory management, International Journal of Applied Business and Economic Research, Vol. 15, No. 8, pp. 29-41, 2017.

[9] RUIZ-TORRES, A.J., MAHMOODI, F.: Safety stock determination based on parametric lead time and demand information, International Journal of Production Research, Vol.48, No. 10, pp. 2841-2857, 2010. doi:10.1080/00207540902795299

[10] JUNG, J.Y., BLAU, G., PEKNY, J.F., REKLAITIS, G.V., EVERSDYK, D.: A simulation based optimization approach to supply chain management under demand uncertainty, Computers and Chemical Engineering, Vol.28, No. 10, pp. 2087-20106, 2004. doi:10.1016/j.compchemeng.2004.06.006

[11] DUTTA, S., SHAH, H., DASARI, A., SINGAL, K., HARIKEERTHI, N.Y., TALAKOLA, Y.R.: Optimizing inventory through ABC classification and demand forecasting, $17^{\text {th }}$ International Annual Conference of the American Society for Engineering Management, 18-21 October, Huntsville, USA, Code 131917, 2017.

[12] ARMENZONI, M., MONTANARI, R., VIGNALI, G., BOTTANI, E., FERRETTI, G., SOLARI, F., RINALDI, M.: An integrated approach for demand forecasting and inventory management optimization of spare parts, International journal of simulation and process modeling, Vol. 10, No. 3, pp. 223-240, 2015. doi:10.1504/IJSPM.2015.071375

[13] BRANDENBURG, M., GOVINDAN, K., SARKIS, J., SEURING, S.: Quantitative models for sustainable supply chain management: Developments and directions, European Journal of Operational Research, Vol. 233, No. 2, pp. 299-312, 2014. doi:10.1016/j.ejor.2013.09.032

[14] BERTRAND, J.W.M., FRANSOO, J.C.: Operations management research methodologies using quantitative modeling, International Journal of Operations and Production Management, Vol. 22, No. 2, pp. 241-264, 2002. doi:10.1108/01443570210414338

[15] GUNASEKARAN, A., NGAI, E.W.T.: Information systems in supply chain integration and management, European Journal of Operational Research, Vol. 159, No. 2, pp. 269-295, 2004. doi:10.1016/j.ejor.2003.08.016

[16] BERLING, P., MARKLUND, J.: A model for heuristic coordination of real life distribution inventory systems with lumpy demand, European Journal of Operational Research, Vol. 230, No. 3, 515-526, 2013. doi:10.1016/j.ejor.2013.04.053 
[17] ANDERSSON, J., MARKLUND, J.: Decentralized inventory control in a two-level distribution system, European Journal of Operational Research, Vol. 127, No. 3, pp. 483-506, 2000. doi:10.1016/S0377-2217(99)00332-X

[18] BOOKBINDER, J.H., LORDAHL, A.E.: Estimation of inventory re-order levels using the bootstrap statistical procedure, IIE Transactions (Institute of Industrial Engineers), Vol. 21, No. 4, pp. 302-312, 1989. doi:10.1080/07408178908966236

[19] OGBO, A.I., VICTORIA, O.I., UKPERE, W.I.: The impact of effective inventory control management on organizational performance: A study of 7up bottling company Nile Mile Enugu, Nigeria, Mediterranean Journal of Social Sciences, Vol. 5, No. 10, pp. 109118, 2014. doi:10.5901/mjss.2014.v5n10p109

[20] LUO, Z., WANG, Y., HU, H.: History-based purchase inventory optimization model and global sensitivity analysis in iron and steel industry, Proceedings of the $201527^{\text {th }}$ Chinese Control and Decision Conference, 23-25 May, Qungdao, China, pp. 4659-466127, 2015. doi:10.1109/CCDC.2015.7162747
[21] SIPONEN, M., KAAPASALO, H., HARKONEN, J.: Maintenance, repair, and operations inventory reduction and operational development, International Journal of Industrial and Systems Engineering, Vol. 32, No. 1, pp. 1-31, 2019. doi:10.1504/IJISE.2019.099780

[22] VEGSÖOVÁ, O., KHOURI, S., STRAKA, M., ROSOVÁ, A., KAČMÁRY, P., BETUŠ, M.: Using technical means and logistics principle applications to solve ecological water course accidents, Polish Journal of Environmental Studies, Vol. 28, No. 5, pp. 3875-3883, 2019. doi:10.15244/pjoes/95183

[23] IVANIČOVÁ, Z., BREZINA, I.: Kvantitatívne metódy pre manažérov, Edícia Ekonómia, Bratislava, 1997. (Original in Slovak)

[24] UNČOVSKÝ, L: Stochastické modely operačnej analýzy. Alfa, Bratislava, 1980. (Original in Slovak)

\section{Review process}

Single-blind peer review process. 